${ }^{\mathrm{I}}$ Universidade Federal de Minas Gerais (UFMG), Departamento de

Comunicação, Belo Horizonte, MG, Brasil

agbrasil@uol.com.br

"Iniversidade Federal do Rio de Janeiro (UFRJ), Departamento de

Antropologia, Rio de Janeiro, RJ, Brasil

marcoatg@terra.com.br

André Brasil '

Marco Antonio Gonçalves "

\title{
CINEMAS E MÍDIAS INDÍGENAS: CONSTRUIR PONTES, RECUSÁ-LAS. ENTREVISTA COM FAYE GINSBURG
}

Com a hospitalidade que lhe é habitual, Faye Ginsburg, professora titular de antropologia na Universidade de Nova York, nos recebeu para esta entrevista no Center for Media, Culture and History (Centro de Mídia, Cultura e História) - $\mathrm{CMCH}$, espaço que criou e que coordena ativamente desde i986. A ideia era apresentar aos leitores brasileiros esse trabalho pioneiro voltado para os processos de descolonização e a experiências de autorrepresentação, tendo o cinema e a mídia como lócus de produção e pesquisa. Acompanhando o percurso acadêmico e teórico de Ginsburg, a conversa seguiria solta, não fosse certa apreensão provocada pelos insistentes alarmes oficiais que recebíamos, via celular, sobre uma tempestade que se aproximava, o que acabou adiantando nossa volta para casa.

A entrevista foi abrigada, em julho de 20I6, pelo $\mathrm{CMCH}$, ao qual estávamos vinculados na condição de professores visitantes, em sala que acusava a vocação do espaço: rodeados por estantes com DVDs e fitas VHS, podíamos sentir ali o trabalho de décadas dedicado ao filme etnográfico e especialmente à produção audiovisual indígena em várias regiões do mundo. Não à toa, o $\mathrm{CMCH}$ é protagonista nas reflexões sobre antropologia, cinema e mídia, ao incorporar e tomar a sério essa produção como propulsora de novas questões que, inelutavelmente, forçam esses campos a repensar conceitos e teorias a partir do diálogo intercultural inscrito nas imagens.

Faye Ginsburg nasceu em 28 de outubro de I952, filha de Benson Ginsburg, importante cientista dedicado às pesquisas sobre comportamento gené- 
tico dos canídeos, o que a levou a compartilhar a infância com os lobos que o pai estudava em seu laboratório na Universidade de Chicago. Tal pesquisa, vale dizer, rendeu análise e inspiração para o livro de Donna Harraway When species meet, que traz uma foto de Faye, aos dez anos de idade, com o lobo Remus (que seria seu anfitrião na vida social dos lobos em interações que seu pai observava cientificamente). Graduando-se em I976 pelo Departamento de Arqueologia e História da Arte do Barnard College, Faye Ginsburg frequentou o Ethnographic Film Seminar (Seminário do Filme Etnográfico) ministrado por Jean Rouch, em I979, em Amherst, Massachusetts. Pós-graduou-se pelo Departamento de Antropologia da Universidade da Cidade de Nova York em I986, defendendo sua tese publicada sob o título Contested lives: the abortion debate in an american community. Desde I986, dedica-se aos domínios do filme etnográfico e da antropologia visual, conferindo-lhes particular visada, qual seja, o crescente interesse pelas imagens produzidas por grupos nativos, tendo em vista seus modos de produção e de circulação, com especial atenção às questões políticas aí implicadas. Sua obra ${ }^{\mathrm{I}}$ bem indica seu universo de interesse e propõe conceitos incisivos, que serão retomados na entrevista.

Anos dedicados às imagens produzidas por grupos nativos de várias partes do mundo permitiram a Faye Ginsburg acompanhar a historicidade das questões interculturais que se abrigam nas imagens, mas que as ultrapassam, exigindo metodologia atenta ao que está visível na tela e também ao que ocorre fora dela. Como defende a entrevistada, a atenção aos processos de produção e de circulação das imagens nos exige questionar a vocação de fluência e transparência própria da tradição imagética ocidental e considerar os protocolos de cada povo, muitas vezes construídos sobre o que se deve ocultar, mais do que sobre o que se deve revelar. Como se notará, a conversa extrapola as discussões em antropologia visual, colocando em evidência questões hoje cruciais, como aquelas em torno da mediação cultural, da propriedade intelectual, da devolução e reutilização dos arquivos.

Sucede à entrevista artigo inédito de Faye Ginsburg, no qual retoma conceitos centrais em sua obra - Faustian contract (pacto faustiano), media sovereignty (soberania midiática) e embedded aesthetics (estéticas "inscrustadas") - e que revisita sua visada ampla acerca das experiências midiáticas sobre comunidades indígenas no mundo, tomando como foco as tecnologias digitais e, mais especificamente, o trabalho com os arquivos. O artigo de André Brasil e Bernard Belisário aborda um conjunto de filmes ameríndios realizados no Brasil: na esteira da afirmação do realizador xavante Divino Tserewahu, observam como, cada qual a sua maneira, os filmes contribuem para "desmanchar o cinema". Aqui, a noção do fora-de-campo, tomada em suas relações com a cena do filme, permite apreender as passagens entre as dimensões do visível e do invisível, abrindo a fenomenologia do cinema para fora dela mesma, ao abrigar traços de cosmologias específicas. Por fim, Marco Antônio Gonçalves retoma o proje- 
to pioneiro Navajo filming themselves, especialmente o filme Intrepid shadows, feito pelo navajo Al Clah, buscando caracterizar a "teoria das imagens" ali proposta, em atenção à cosmologia navajo, para, em seguida, tomar a categoria do intruso como central na compreensão do filme, em seu movimento de alteridade e alteração. Em diálogo com os conceitos e ideias abordados na entrevista, os três textos guardam em comum a abordagem dos filmes indígenas como experiências que endereçam questões à antropologia, ao cinema e aos media, de modo a alterar seus dispositivos e maneiras de representação, e que, também, abrem as imagens para fora delas mesmas, fazendo com que atravessem questões políticas e cosmológicas.

Marco Antonio Gonçalves. Em seu artigo "Repensando o documentário na era digital" você diz que os filmes de Jean Rouch lhe despertaram o desejo de iniciar uma pós-graduação em antropologia. Poderia nos falar mais sobre seu interesse por Rouch, e, mais amplamente, pelo filme etnográfico?

Faye Ginsburg. Interessei-me por filmes e antropologia quando, ainda na graduação, comprei minha primeira câmera de vídeo, hoje um objeto histórico. Com mais dois amigos começamos a fazer alguns documentários, e, ao observar como esses trabalhos circulavam, percebi o potencial e o alcance de um filme.

Em I 978, Jean Rouch veio a Nova York para o primeiro Margaret Mead Film Festival. Foi a primeira vez que vi seus filmes, que muito me intrigaram. Afinal tive muita sorte: no verão de 1979 Jean Rouch veio aos Estados Unidos para ministrar um curso intensivo durante duas semanas. Na verdade naquela época ele ministrou vários cursos. Primeiro em Harvard e depois no Hampshire College, em Amherst, um lugar muito bonito no campo, em Massachusetts. Pensei então que seria interessante seguir este último curso e fiquei completamente tomada não apenas pelo que Jean Rouch ensinava, mas também pelo modo como ensinava. Havia muita gente interessante naquele seminário, jovens documentaristas, pessoas interessadas em cinema experimental, e isso tudo era muito fascinante para mim. Rouch trouxe alguns palestrantes convidados, alguns amigos dele, como John Marshall, Richard Leacock e Tim Asch, que apresentavam e comentavam seus trabalhos. Eu tinha, já naquela época, a percepção de que aquele era um momento realmente inventivo para o cinema etnográfico. Ao investigar as possibilidades do filme etnográfico, as pessoas estavam ampliando as fronteiras do próprio cinema.

Nessa época, eu sentia certo desconforto, ficava mesmo aflita diante da relação entre a história colonial e a antropologia. Eu ainda não havia compreendido bem essa relação até o encontro com Rouch. Ao ver seu trabalho e ouvir o que ele nos ensinava percebi o modo contundente como ressignificava a antropologia, sobretudo a partir do conceito de antropologia compartilhada que resultara nos filmes incríveis que realizou com seus amigos na África. Esse encontro com Rouch despertou fortemente meu interesse e me inspirou a que- 
rer fazer filmes e a me lançar na investigação sobre a relação entre antropologia e história colonial. Naquela época eu ainda tinha um pouco de resistência à ideia de fazer pós-graduação, mas me animei com a possibilidade de trilhar algo na linha do que Rouch havia feito.

Consegui então trazer Rouch pela primeira vez à Universidade de Nova York no contexto de uma exposição no Metropolitan em torno da arte dos Dogon do noroeste da África, com os quais Rouch havia trabalhado nos anos 40 e 50, junto com Marcel Griaule. Contatei o curador da exposição e propus que Rouch viesse apresentar seus filmes sobre os Dogon, que aqui não eram muito conhecidos. O Metropolitan aceitou a proposta, e então pudemos fazer uma primeira mostra de seus filmes, realizando ainda uma série de exibições de outros trabalhos aqui na NYU com sua participação e seus comentários. Em um encontro que foi extremamente produtivo, trouxemos também Manthia Diawara, que é do Mali, estava lecionando na Califórnia e já tinha encontrado Rouch em Paris. Posteriormente, em I988 e em 2000, exibimos todos os seus filmes de etnoficção, em mostra organizada com Diawara e, também, com Steven Feld. Todas as entrevistas com Rouch foram transcritas por Jamie Berthe, que na época era ainda estudante e atualmente é professora aqui. Exibíamos o filme - por exemplo, Cocorico Monsieur Poulet (I974) ou Jaguar(I967) -, e Rouch os comentava e respondia às perguntas, o que resultou em material excepcional sobre seu trabalho.

André Brasil. E como surgiu seu interesse pelo cinema indígena?

F. G. Antes de inaugurar o Centro de Mídia, Cultura e História aqui na Universidade de Nova York, eu tinha experiência em diferentes interfaces. Trabalhei durante algum tempo numa estação de televisão em Minneapolis; havia realizado um trabalho etnográfico sobre mulheres contrárias ao aborto, consideradas conservadoras e de direita, do movimento Prolife. Lembro-me de que este foi um grande desafio para mim: fazer etnografia sobre mulheres de direita... os antropólogos não gostam de arriscar suas credenciais de esquerda.

Interessei-me pelo cinema indígena quando comecei a trabalhar na NYU, em I986, ainda em dedicação parcial, já que nessa época eu lecionava também na New School. Fui convidada por Annete Weiner, então chefe do departamento de antropologia, para iniciar um programa em torno do filme etnográfico na NYU. A direção da universidade contratara Annete Weiner ${ }^{2}$ porque ela era uma estrela ascendente na antropologia e contribuiria para o objetivo de mudar o perfil do departamento. Ela estava muito interessada em antropologia visual e, ainda que eu estivesse terminando meu doutorado, convidou-me para iniciar o programa. Fez questão de conseguir o auditório no andar térreo para os cursos que eu iria ministrar e equipá-lo de modo a criar ali boas condições de exibição dos filmes. Na primeira conversa com Annete insisti em afirmar que gostaria de propor algo novo, que fosse deliberadamente distante de certo legado colonial do filme etnográfico. Tinha em mente o 
desejo de endereçar o gesto de descolonização a esse domínio. Comecei pelo nome do Centro, apostando na ideia de mídia e cultura, para justamente ampliar o conceito de antropologia visual. Queria que o Centro pudesse envolver, por exemplo, o som, já que alguns de nossos alunos estudavam o rádio.

Nessa época eu admirava o trabalho realizado no Museu do Índio aqui em Nova York, sobretudo o de Elizabeth Weatherford, que fez muito pelo cinema indígena. Ela dirigia uma seção, para a qual Amalia Córdova ${ }^{3}$ veio a colaborar, sobre o cinema indígena então emergente. Comecei a ver os filmes que se exibiam lá. Logo compreendi que, se os estudantes pudessem assistir aos filmes indígenas como parte de sua formação, isso contribuiria para descolonizar o modo como pensavam os outros povos e a própria antropologia. Fazê-los entender que o fato de estudarem numa região privilegiada do mundo não lhes daria o direito de entrar em qualquer outro lugar do mundo com uma câmera na mão e tomar imagens, nem por razões políticas nem culturais. Queria sensibilizá-los para a ideia de quão complicado era o gesto aparentemente simples de adentrar os lugares e produzir imagens.

Outra coisa que me levou ao cinema indígena foi o encontro com Fred Myers, ${ }^{4}$ que era grande amigo de Annete Weiner. Comecei, então, por seu intermédio, a tomar conhecimento dos projetos em curso na Austrália. Fred conhecia as pessoas que trabalhavam com projetos de mídia pioneiros por lá. $\mathrm{Na}$ metade dos anos 80 instalaram um sistema de comunicação via satélite na Austrália Central, e as pessoas que estavam vivendo em áreas as mais remotas tiveram, de repente, acesso à televisão. Isso era ameaçador: a sedução da TV para os jovens era grande, a pornografia começava a entrar, e as comunidades tinham muitas questões a enfrentar. Um pesquisador que trabalhara com Sol Worth, ${ }^{5}$ do projeto com os Navajo, foi contratado para analisar os efeitos da televisão entre os aborígenes. Ele era uma espécie de ativista e levou algumas câmeras de vídeo no intuito de que os aborígenes inventassem sua própria televisão. Quando tomei conhecimento dessa experiência pensei de imediato que esse seria um material fantástico para ensinar e pesquisar, para propor em meus cursos. Fui com Fred Myers para a Austrália Central desejosa de conhecer melhor esse projeto e ter acesso ao material. Mas os tempos eram outros, e não era fácil fazer cópias dos vídeos. Eric Michael, o idealizador do projeto, morreu pouco antes de eu chegar à Austrália, e infelizmente nunca tive oportunidade de encontrá-lo. Dele e de sua experiência herdei a tarefa de fazer com que as pessoas entendessem como era promissor e importante o trabalho que havia realizado e o quanto era rico todo esse material produzido pelos aborígenes.

M.A.G. O que você intuiu ou percebeu como importante ali, nesse material em específico?

F.G. A primeira coisa que aprendi, ao chegar nas comunidades e pedir para ver os vídeos, foi que muitos deles eram interditos, dado que algumas das pessoas 
filmadas tinham morrido. Para os aborígenes ver a imagem de um parente morto pode ser fatal para quem as vê. Não se deve sequer pronunciar o nome de um morto, interdito que se expande para as imagens. Para se referir aos mortos usam nomes diferentes dos reais, e os objetos pessoais são também destruídos, incluídas aí as fotografias. Por mais que haja muitas diferenças culturais entre os aborígenes na Austrália, essa interdição parece ser generalizada. Logicamente, isso mudou muito nestes últimos 20 anos. No começo, pensei: como ver esses filmes, o que fazer? Mas logo depois entendi que esse fato era em si mesmo de interesse, algo que nos forçava a pensar que, para além das imagens produzidas, havia uma concepção, uma ontologia da imagem que incluía esse fora-de-quadro e que determinava a possibilidade ou não de sua exposição.

Eu estava na Austrália em I988, no momento dos protestos contra a celebração oficial dos 200 anos de descoberta do país organizados pelos movimentos indígenas, que a nomearam "o dia da invasão". Enquanto havia uma tentativa de produzir representações nacionais na mídia oficial australiana, essas comunidades remotas estavam desenvolvendo suas próprias mídias. Mesmo os aborígenes urbanos desejavam construir um espaço para realizar a formação como videomakers em canais da TV australiana. Meu background na televisão, no início de minha carreira, contribuía para o investimento nessas questões, e então decidi começar a pesquisar e escrever sobre o tema da emergência das mídias indígenas, assim como sobre as questões políticas e culturais que ali aportavam.

No ano seguinte dessa viagem, minha filha nasceu com uma doença muito rara, com muitos problemas médicos, o que restringiu minha possibilidade de viajar. Resolvi então iniciar o Centro aqui em Nova York e durante seis anos consegui fundos dos mais diversos, provenientes de fundações de pesquisa e de instituições ativistas, como forma de ajudar os cineastas indígenas a divulgar seu trabalho. Logo entendi que muitas dessas pessoas não poderiam ausentar-se de suas aldeias e comunidades por um longo período, podendo, entretanto, realizar curtas estadas com bolsas de pesquisa. Passei, então, a convidar para cá cinegrafistas e líderes de projetos de mídia entre os povos indígenas, por exemplo, Vincent Carelli, ${ }^{6}$ do Vídeo nas Aldeias. Encontrei-o quando ele exibia os filmes do VNA no Museu do Índio Americano, e desde então ficamos muito amigos. Mostrei-lhe o acervo dos aborígenes da Austrália. Em I 992 estive em São Paulo, quando Virginia Valadão, então casada com Carelli, ainda estava viva e atuante no projeto. Lá pude ter acesso ao que estavam fazendo naquele momento, e isso foi extremamente importante para minha trajetória.

Assim, passavam por aqui muitos cineastas e escritores indígenas provenientes da Austrália, do Canadá, de diferentes partes da América, ativistas negros de Trinidad. Muita gente esteve aqui e nos ajudou a construir este 
Centro. Em cada uma das visitas, eu apresentava o projeto do convidado, exibindo e comentando seus trabalhos. O mais importante era expor os estudantes a tudo isso. Sempre levei em consideração que tínhamos também alunos de cinema e não apenas de antropologia, e apostava que a produção de um cosmopolitismo local na NYU garantiria que eles pudessem ter contato direto com os realizadores, o que seria transformador em sua formação intelectual.

Com essa abertura, conectávamos também diferentes instituições, como o Museu do Índio Americano, o Museu de História Natural, o Museu de Arte Moderna. Nessa época o Moma tinha um curador que foi pioneiro em exibir filmes indígenas numa instituição tradicionalmente orientada para o que se considerava a alta arte ou alta cultura. Em 2005, colaboramos com o Museu do Índio e o Moma no programa "Primeiras nações, primeiros filmes". A ideia era trazer para cá e colocar em contato pessoas que tivessem feito seus primeiros longas-metragens. Durante dez dias mostramos seus filmes no Moma e no Museu do Índio de Washington. O importante é que havia gente de muitos lugares, como os Maori, os Sami, indígenas da Austrália, do México, algo importantíssimo para nós, na universidade. O contato com alguns estudantes resultou em pesquisas como, por exemplo, sobre a TV Maori e as experiências de mídia indígena no México.

Para mim foi difícil o impedimento de viajar com frequência, mas, por outro lado, isso me fez buscar soluções aqui mesmo para realizar essas pesquisas e essas conexões na cidade de Nova York. E isso era um dos aspectos mais gratificantes na construção deste Centro. As pessoas que vinham para cá eram muito generosas em partilhar suas experiências conosco. Isso era também, a meu ver, uma espécie de descolonização da pesquisa. Eram os nativos, agora, que vinham compartilhar suas experiências conosco na universidade.

A.B. A partir dessa trajetória, que transformações (políticas e estéticas) você destacaria no domínio do filme etnográfico e especialmente da mídia indígena? F.G. Vejo hoje uma descolonização mais ampla desse campo. Há outras experiências que emergem, provocadas pelo modo como as câmeras circulam atualmente. Outro fato notável é a proliferação dos festivais de cinema indígena em toda parte, na América Latina, no Caribe, no Canadá, na França, o que suscita muito mais conhecimento e reconhecimento dessa produção.

No campo do filme etnográfico, que é espaço ainda circunscrito, eu ressaltaria a emergência da chamada etnografia sensorial de Harvard, desenvolvida por Lucien Taylor, meu colega e amigo, no The Sensory Ethnography Lab (SEL). Admiro a aventura e a ousadia das produções do laboratório, ainda que tenha algumas ressalvas. O que me preocupa talvez seja o risco de se abraçar a etnografia sensorial como um modelo e de se tomar esse modelo como a única forma de realizar filmes etnográficos. Eu não quero dizer com isso que Lucien Taylor e outras pessoas no grupo de Harvard promovam essa ideia, mas, 
de todo modo, me preocupa o discurso construído em torno deles: o de que existiu no passado um modelo para o filme etnográfico que teria sido hoje substituído pela etnografia sensorial. Indiretamente, isso me parece parte de um desejo de reinstaurar o privilégio masculino no campo do filme etnográfico, que sempre foi tão dominado por homens, mesmo com Jean Rouch. De algum modo, essa área permanece prioritariamente masculina e penso que a emergência do Laboratório de Etnografia Sensorial, embora essa não seja a intenção de seus criadores, reitera esse privilégio. Acho fantástico que esse projeto tenha conquistado espaço e reconhecimento; porém, há questões políticas que merecem discussão: novamente, como pegar uma câmera, entrar em um lugar ou em uma comunidade e produzir imagens ali? No filme Leviathan, por exemplo, o modo como tratam os sujeitos humanos é bastante desconcertante. Se o filme é muito bem feito, um experimento inovador com a câmera gopro, por outro lado, permanece desconcertante para mim o modo como ele se engaja com as pessoas filmadas, pessoas com quem manteve relação de compartilhamento e que afinal são retratadas e representadas como se não tivessem nada a dizer sobre suas vidas.

Por outro lado, o campo da mídia indígena cresceu muito, teve um verdadeiro boom; muita coisa aconteceu e está acontecendo. Recentemente, estão sendo finalizados seis livros resultantes de pesquisas de campo sobre mídias indígenas ligadas às artes. Há algum tempo, escrevi sobre um americano estabelecido na Austrália que questionava a mídia indígena, considerando-a mais uma tecnologia colonial. Esse era o debate que se fazia no começo, e, observando as experiências atuais, fico feliz em perceber que essa visão não vigora mais. Tornou-se uma falsa questão. Pensar que a câmera nas mãos dessas pessoas é uma tecnologia colonial é, no limite, torná-la equivalente ao álcool, ao açúcar, à cristianização, aos genocídios. É desconsiderar que, quando as pessoas pegam a câmera, utilizam-na para afirmar e potencializar os direitos humanos, para filmar suas cerimônias, transmitir conhecimentos intergeracionais. Me espantaria que ainda hoje pudéssemos encontrar essa concepção política e cultural reacionária em relação ao uso da câmera pelos indígenas.

M.A.G. Você formulou muitos conceitos que impactaram o modo de pensar o cinema indígena apontando sua importância em propor novos desafios e problemas para a antropologia e o cinema. A começar pela ideia de parallax effect (efeito de paralaxe), que introduz uma nova perspectiva estética e política no momento em que os indígenas assumem a câmera e a produção dos filmes.

F.G. Trabalhei sobre esse tema no final dos anos 80 e começo dos 9o. Desconfiava haver certa resistência em introduzir o tema da mídia indígena como relevante, incorporando-o numa conversação séria. A dificuldade era aceitar a crítica implícita ou explícita que essa produção oferecia para a antropologia, uma vez que exigia dos antropólogos um deslocamento, a saída de uma posi- 
ção privilegiada para que os filmes pudessem ser trazidos ao diálogo. Eu estava tentando, nesses primeiros escritos, dar conta da recepção dos filmes e do que eles implicavam para a antropologia, e a metáfora da paralaxe me pareceu adequada. Ela dizia do efeito que os filmes criavam no âmbito da antropologia: no processo de construção da visão tridimensional, seu olho produz diferentes ângulos, e, no momento em que seu cérebro processa esses ângulos, é possível ver os objetos de modo tridimensional. Trata-se de uma metáfora. Quando observa o cinema indígena australiano, você tem acesso a uma percepção muito distinta, o que ajuda a compreender um mundo culturalmente complexo. E o potencial disso é que não ficamos limitados a um único gênero de representação, tendo acesso, na tela, ao modo como as pessoas se representam. Fora da tela, vemos também seus efeitos sobre as imagens, uma vez que os australianos podem dizer que não se deve ver esses filmes porque neles aparecem pessoas que já morreram. Temos a ilusão de que a câmera é transparente, disponível para qualquer um, portando sempre a mesma função ideológica e ontológica. Do mesmo modo que um pesquisador que avalia a TV dos aborígenes australianos imaginando que a câmera estivesse embebida, ela mesma, na ontologia do Ocidente e que, por isso, produziria efeitos universais. Isso não é absolutamente verdadeiro, uma vez que cada grupo vai usar a câmera e as imagens de um modo específico, vinculado a sua experiência cultural.

Nesse sentido, não deveríamos nos concentrar apenas nas imagens e nos sons produzidos, mas sobretudo estar atentos ao modo como as imagens e os sons são usados. Quando, por exemplo, os aborígenes criam filmes urbanos para a televisão nacional, recriam suas próprias histórias a partir de seu ponto de vista. A ideologia oficial australiana apagara a existência de pessoas com um ponto de vista sobre o mundo simplesmente os designando como selvagens. Nessa nova condição de representação, sob a mediação da câmera, esses grupos querem justamente acusar o genocídio mostrando que constituem um povo extraordinário e que continuam a lutar por seus direitos. Quando, entretanto, se redesenha uma nova história da Austrália ou se procura recuperar essa história surgem as imagens dessas pessoas. Incluir legendas, precedendo os filmes aborígenes realizados para a televisão nacional australiana, que alertam para o fato de que algumas das pessoas filmadas já morreram - e tudo isso ainda é transcrito para a linguagem oral na língua da região em que o filme foi realizado - passou a ser rotina na Austrália. Isso me parece significativo, pois se trata do reconhecimento, por uma importante televisão nacional, dessa outra concepção de imagem.

Temos que reconhecer que as tecnologias midiáticas são muito complexas e têm vida fora da tela, efeitos fora da tela. E, vejam, quando alguém se espanta com o fato de que os aborígenes não gostam de ver as imagens de seus mortos na tela, é preciso lembrar que nossa cultura também restringe determinadas imagens a determinados públicos, e que as imagens sempre 
implicam restrições. Muita coisa mudou na Austrália, e hoje em dia seus habitantes parecem bem menos restritivos em relação ao tema da morte: as imagens dos mortos passaram a se proliferar de tal forma, que essa circulação levou mesmo a uma ressignificação de sua importância. Hoje as pessoas produzem imagens dos túmulos dos mortos, e isso contrasta com a época em que estive lá, quando essas imagens eram realmente tabu. As novas gerações, de fato, indigenizaram os filmes e a fotografia, e estão muito à vontade frente a esses novos equipamentos e imagens que não são percebidas como objetos impostos pelo governo colonial.

A.B. O efeito paralaxe varia historicamente e diz respeito aos filmes e ao modo como são exibidos, aproximados, cotejados...

F.G. Eu fico particularmente feliz de ter podido, na primeira semana de meu seminário de pós-graduação, projetar o filme Nanook of the North, de Robert Flaherty, seguido do filme Atanarjuat, The Fast Runner (200I), dirigido pelo inuit Zacharias Kunuk. Atanarjuat mostra como os povos indígenas realizam seus filmes com base em lendas e mitos, com atores não profissionais que atuam e constroem coletivamente a história a ser narrada em imagens. O que esse filme e tantos outros realizados pelos indígenas nos ensinam é que ninguém tem uma licença exclusiva para representar os povos indígenas remotos ou os povos não ocidentais. Esse ponto parece fundamental para se entender a força da mídia indígena e, desde a primeira aula de meu seminário, enfatizo esse gesto de descolonização quanto a ideias preconcebidas sobre cinema, imagem e tecnologia; ressalto que devemos sobretudo pensar sobre nossas próprias representações. Temos que repensar nosso privilégio de representar esses povos e o modo como os representamos. E isso me traz sempre de volta a Jean Rouch, à maneira como ele opera esse questionamento em seus filmes.

Colaboro já há algum tempo com a organização do Festival Margaret Mead em Nova York e pude observar como se tornou rotina os festivais apresentarem filmes de realizadores indígenas. Tenho, porém, a impressão de que, no Brasil, essa prática é ainda mais presente. Penso haver no Brasil mais ampla participação indígena nos festivais dedicados ao filme etnográfico e documentário. O que me parece crucial é colocar juntos os filmes etnográficos e os filmes dos indígenas. No Brasil, estes últimos ocupam lugar importante visto que são extremamente potentes e parecem circular muito mais em diferentes meios; foram desde os primórdios reconhecidos como um modo de descolonização da antropologia e das representações. Intuo, aliás, que as novas gerações de estudantes estejam mais acostumadas com os filmes indígenas: lembro, por exemplo, no que ocorre agora, no segundo semestre de 20I6, na UFMG, onde o cineasta xavante Divino Tserewahú ministrará um curso sobre as práticas cinematográficas e suas concepções, permitindo que os jovens universitários possam ter acesso direto a suas ideias. Isso, penso eu, é realmente fantástico, mais 
ainda quando se fizer disso uma rotina e não uma exceção: quando os cineastas indígenas puderem usufruir de um lugar de interlocução conquistado.

Poderia ressaltar, também, que a mídia indígena sugere muitas inovações no modo de abordar certos temas. Menciono como exemplo o trabalho de uma pesquisadora de Manchester que, ao propor um projeto de formação e realização de filmes para um dos povos indígenas brasileiros, se dá conta de que as mulheres estavam interessadas em discutir os arranjos matrimoniais naquela comunidade a partir de significativas mudanças culturais e sociais. E elas o fazem de um modo inusitado, não mais realizando um documentário clássico, mas adotando a forma da telenovela para contar suas histórias. A própria concepção de telenovela é ressignificada quando elaborada pelas mulheres indígenas. Essas reinvenções ocorrem quando se privilegia outras estratégias de representação.

Outro exemplo é o de uma aborígene australiana que realizou uma instalação no Festival Margaret Mead usando incríveis e loucas iconografias que achou na internet sobre os aborígenes, sobretudo aquelas ligadas a seus ancestrais totêmicos. Ela reconstrói essas imagens de um modo também inusitado. Isso para demonstrar como as tecnologias e as formas de representação podem ser alteradas por dentro.

Hoje em dia convivemos com tecnologias de realidade virtual que mudam nossa percepção e que serão em breve utilizadas pelos indígenas de modo transformado. Não se trata, no entanto, de uma apologia aos modos midiáticos de suporte imagético. Não desconsideremos, por exemplo, o rádio que se mantém uma das mais importantes entre as formas de comunicação do planeta, com base em tecnologia extremamente acessível.

E se a antropologia visual conecta tudo estreitando os laços entre os indígenas e nós, a linguagem que utilizamos é restrita e não dá conta do que realmente está acontecendo nessas múltiplas experiências dos povos indígenas com as mídias e as comunicações. Isso tudo para mencionar e retomar, quem sabe, o significado do efeito de paralaxe por outra perspectiva.

A.B. Em outro conceito - embedded aesthetics - você considera os aspectos formais/estéticos inseparáveis dos aspectos sociais e políticos na construção das imagens. Como, metodologicamente, fazer essa relação entre o que está na tela e o que está fora da tela?

F.G. Essa questão é crucial para repensar a estética. Nós temos uma ideia muito ocidental de que a estética seja estritamente uma materialização formal. Se isso pode ser parcialmente verdadeiro, devemos estar atentos ao fato de que existem outras relações que se estabelecem na produção e apreciação das imagens. Deve-se levar em conta, por exemplo, que o fora-da-cena pode definir e tornar inteligível uma imagem mais do que a imagem propriamente dita. Não são raros os casos do cinema indígena em que, para determinada cerimô- 
nia ser filmada, é necessário que aquele que irá filmar tenha uma relação apropriada e autorizada para fazê-lo. Caso não se garanta essa relação, a filmagem é tomada como não "verdadeira". Parece estranho pensar assim, mas o que é enfatizado nessa ontologia das imagens é o fato de que, mais importante do que as imagens em si, talvez seja o modo como são produzidas, as relações implicadas em sua produção.

Algo semelhante também ocorre na produção das pinturas pelos aborígenes australianos, que são consideradas verdadeiras quando tratam de histórias sonhadas e quando são retratadas por alguém que tenha direito de narrar/pintar essas histórias. Não importa o quanto se pareçam figurativamente com aquilo que representam: as pinturas serão julgadas adequadas e verdadeiras somente quando associadas a um modo apropriado de construção. $O$ importante nesse "modo" da estética é que seja assumido por pessoas que têm o direito de produzir as pinturas.

O que quero dizer com tudo isso é que estamos muito acostumados com o discurso da qualidade e do valor das imagens. É nesse contexto que defino o conceito de embedded aesthetics, na tentativa de pensar estética como algo que faz parte também da ordem das relações sociais. Terence Turner,7 quando escreve sobre a estética da repetição e sua importância na vida social dos Kaiapó, está tratando de um fenômeno semelhante. Essa percepção estética kaiapó nos reenvia a outro problema: como os rituais filmados poderiam ser editados uma vez que a própria repetição é o que importa na construção das imagens? Isso é relevante para pensar como os Kaiapó, uma vez defrontados com a produção de filmes, podem traduzir ou "indigenizar" a seu modo a prática cinematográfica a partir de sua percepção estética particular. Essas são questões muito relevantes para a antropologia. Os materiais indígenas nos proporcionam esse questionamento, posto que nos fornecem alteridade radical que questiona pressupostos e regras ocidentais estabelecidos sobre a imagem, o cinema. Essa não é uma questão exclusiva do filme etnográfico, mas também do cinema indígena, uma vez que não se pressupõe entendimento universal para aquelas imagens; uma vez que o que está fora da tela é muito importante ou quase tão importante quanto o que está na tela. E acho que daí advém minha percepção do sentido de etnografia. Se a etnografia é algo que tem interesse na coisa em si mesma, ela é, também, um modo de ir para além da coisa em si mesma.

M.A.G. Dadas a circulação e a repercussão de alguns filmes indígenas nos contextos de festivais e exibições, surge, então, a questão da autoria. Quais as relações entre mídia indígena e novas formas de autoria?

F.G. Estamos acostumados com as formas dominantes de autoria impostas pelos filmes, festivais e redes de televisão que se apoiam na ideia do diretor, um nome que deve estar vinculado àquela forma de realização. Esse tipo de atribuição oculta o sentido de trabalho coletivo e de autoria compartilhada 
muitas vezes experiementado pelo cinema indígena. É o caso dos filmes produzidos no projeto Isuma TV pelos Inuit que, embora tenham claramente um líder que provoca e faz as coisas acontecerem, têm um trabalho fundamentalmente coletivo. Assim, seria um erro tomar Zacharias Kunuk como um diretor de cinema no sentido ocidental do termo; cabe antes encarar seu trabalho como algo realmente coletivo, com base em uma comunidade de criação. Por outro lado, existe todo um esforço em individualizar os cineastas, como o que é apresentado no próprio website do projeto Isuma $\mathrm{TV}^{8}$ na seção Estilos individuais de filmar, na qual se expõe o modo como cada um deles trabalha. Se há um esforço de circular os filmes em festivais e no cinema, associando-os ao nome de um diretor e à ideia de autoria, existem, por outro lado, produções como aquelas realizadas na Austrália Central que se baseiam em sonhos: são histórias herdadas por alguém e passadas para outras pessoas que têm o direito sobre aquelas narrativas que não podem circular fora de determinados círculos de indivíduos, homens ou mulheres iniciados, uma vez que eles detêm o direito de narrá-las.

As questões de propriedade cultural e autoria em relação aos indígenas nos permitem perceber como as ideias ocidentais de autoria e de propriedade são limitadas e não dão conta de processos amplos levados adiante por outros povos. Isso nos faz retornar ao conceito de embedded aesthetics, uma vez que nos abre uma via epistemológica e ontológica para ultrapassar a tela, levando-nos além da imagem que efetivamente vemos.

A.B. Você usou em seus artigos o conceito de epistefilia, tal como formulado por Bill Nichols ${ }^{9}$ (como um paralelo ao conceito de escopofilia, baseado na noção de prazer e erotismo). Entretanto, apontou em seus escritos que o cinema indígena não estava apenas interessado em incitar prazer ou conhecimento, mas definitivamente mediação. Em sua opinião como o cinema indígena desafia essa noção de epistefilia formulada para o documentário?

F.G. O conceito de epistefilia desenvolvido por Bill Nichols se associa à ideia de que a prática do documentário ocidental é dirigida pelo desejo de conhecimento; e, se isso pode ser verdade também sobre os filmes etnográficos, devemos estar atentos ao fato de que os filmes etnográficos têm outro estatuto no mundo do documentário. Esse é um ponto interessante para pensarmos quem representa e apresenta esse conhecimento em forma de filme sobre outros mundos distantes, tendo a capacidade de estabelecer uma mediação. Quando nos deparamos com os filmes dos indígenas, como, por exemplo, aqueles do projeto Vídeo nas Aldeias, no Brasil, percebemos que o trabalho ali é primeiramente interno ao próprio grupo: eles filmam a seu modo as próprias cerimônias, produzindo formas intergeracionais; outros filmes têm viés mais político, e suas histórias estão vinculadas ao direito à terra e aos diferentes modos de reivindicação e engajamento. 
Esse tópico me lembra os primeiros trabalhos dos Hopi, creio que os primeiros indígenas a experimentar a realização de filmes. São opacos, restritos àqueles que têm direitos e conhecimento sobre a cultura hopi. Há um filme dos Hopi cuja circulação foi interditada para exibição pública, mas que pode ser visto de forma privada. O que quero assinalar é que o modo como deliberadamente essa opacidade nos filmes foi produzida é em si mesmo uma estratégia para gerar outras formas de representação e exibição. Temos, portanto, um filme que, para quem não é hopi, torna-se quase impenetrável; não se trata de um filme que permite a quem assiste entrar no mundo dos Hopi, ampliando seu conhecimento sobre esse mundo. Essa deliberação de seu diretor é justamente uma tentativa de desenvolver uma forma fílmica opaca, que intervém nas discussões sobre autoria e propriedade cultural ao questionar, primeiramente, quem tem o direito de conhecer os rituais e protocolos dos Hopi e de ver aspectos de sua cultura. Questiona o que parecia óbvio e esperado: que as imagens estivessem lá, disponíveis para ser vistas e compreendidas. Esses são filmes produzidos a partir da reflexão e da consciência do que pode ou não pode ser visto. Em outro exemplo, citaria o artista hopi que, em eventos públicos, insiste em falar apenas em hopi, algo que se mostra como opção deliberada já que seu inglês é perfeito (ele estudou em Princeton). Uma consciência sobre o que não se quer revelar.

A questão é justamente a de demonstrar que nem tudo está à disposição para ser apreciado, visto e compreendido pelo olhar ocidental. Retornamos então à questão do que está sendo (e pode ser) mediado. Isso também nos reenvia ao conceito de embedded aesthetics. Encontrei esse mesmo exemplo de opacidade em outro artista australiano que esteve expondo em Nova York recentemente, tendo recebido ótima crítica nos jornais. Quando perguntado sobre o modo como suas pinturas estavam relacionadas com as narrativas oníricas, ele simplesmente disse: "eu não sei". Isso é fascinante para pensarmos como as mídias e os filmes podem ser utilizados para aproximar e construir pontes entre os mundos, mas também para recusar essas pontes e para não torná-las completamente transparentes. E isso sugere algo diferente da ideia de epistefilia de Nichols, já que as pessoas podem estar fascinadas pelos documentários, sem necessariamente os entender; eles não despertam naturalmente desejo de conhecimento e de transparência e não respondem necessariamente a isso.

M.A.G. Em seu artigo "Repensando a era digital", você apontou o paradoxo da tecnologia e da tradição, a grande divisão que esse conceito quer produzir ao reinstaurar o etnocentrismo e o evolucionismo. Você, portanto, introduz outro conceito, "indigenizar a tecnologia", com a intenção de mudar o modo de se perceber a "era digital". Poderia elaborar mais sobre esse tópico relacionado ao cinema indígena? 
F.G. O projeto Vídeo nas Aldeias, por exempo, trabalha sobre materiais culturais reenquadrando-os e usando vídeo ou outras tecnologias de diferentes modos, seja para registrar rituais, seja para o ativismo político e cultural, interferindo nos processos históricos em que se encontram. As novas gerações estão cada vez mais capacitadas em relação às tecnologias digitais, sobretudo às câmeras e à produção de imagens. Esse é, de fato, um diferencial intergeracional, e isso faz com que os jovens participem de modo renovado das práticas rituais ou dos processos culturais que os mobilizam.

Já nos primeiros estudos que realizei sobre mídia indígena, junto à Associação Australiana de Mídia, pude notar como todos os jovens estavam muito confortáveis ao lidar com as mídias. A partir dessa habilidade, eles podiam engajar-se com os mais velhos e estabelecer conversas talvez impossíveis sem as mídias como mediação. Com a câmera eles estableciam um protocolo de respeito, modos apropriados de realizar entrevistas, sem pressa, na duração adequada, respeitando o tempo dos entrevistados; podiam transcrever todas as entrevistas e traduzi-las, e isso era um modo interessante de atuação cultural que pode ser observado em tantos outros povos quando entre eles se introduzem mídias e tecnologias.

A presença das mídias é crescente entre as populações indígenas. Percebo, por outro lado, uma espécie de fantasia utópica da comunicação, que aposta na ideia de que, um dia, todos os povos indígenas estarão se comunicando entre si. Essa me parece uma forma ocidental hegemônica de pensar, que toma tudo como transparente e acessível ao consumo. O acesso é variável, assim como o que se inventa com as tecnologias: por um lado, há cada vez mais bandas largas de internet mundo afora, essas que fazem parte das fantasias promovidas pela indústria da tecnologia digital. Por outro lado, existem muitos lugares que só conseguem receber sinais de rádio; existem lugares que possuem um computador para toda a aldeia, lembrando que esse é um equipamento que não pode ser consertado com facilidade. O mesmo se dá com o vídeo em lugares remotos, como a Austrália ou a Amazônia. A Isuma TV no Ártico tem acesso muito precário à internet, ficando às vezes uma semana sem sinal, o que força seus produtores a criar e inventar novas formas de usar a tecnologia, algo que eles próprios chamam de "democracia indígena digital" e assim reivindicam. Esse processo se acelerou no Ártico, onde muitas companhias de mineração se instalaram, e eles não têm capacidade de controlar a situação. Tentam usar a conectividade de internet para construir encontros políticos virtuais, uma vez que o Ártico é imenso e lá é difícil a locomoção.

Assim é preciso, de fato, desocidentalizar essa fantasia sobre a era digital. Não se pode dizer que todos vivem na era digital só porque se relacionam com meios digitais. Não se trata de que alguns povos não querem ou não usam as tecnologias, mas sim de percebermos que a chamada era digital pode criar um grande divisor entre os povos que têm acesso a essa tecnologia e aqueles 
que, por não a utilizarem, podem ser considerados atrasados em uma escala guiada pela fantasia de que o progresso digital deve ser estendido a todos os povos. Assim, as tecnologias digitais são hoje a imagem e a linguagem do que se entende como o Ocidente desenvolvido, mas não deveriam ser a "medida" para a experiência de todos os povos.

A.B. Há um processo importante em curso hoje, de certo modo favorecido pelas tecnologias digitais, que diz respeito à devolução dos arquivos e sua utilização pelos povos indígenas: Como você aborda a reapropriação de arquivos de imagens em filmes indígenas?

F.G. A questão dos arquivos sonoros e imagéticos é extremamente interessante para pensarmos novamente a propriedade intelectual e a autoria. A maioria dos arquivos, sobretudo aqueles constituídos no século XIX com gravações ou fotografias dos povos indígenas, está vinculada a quem realizou a gravação e não aos povos filmados, que continuam sem acesso a esses materiais. Existem, contudo, trabalhos e iniciativas louváveis desenvolvidos, por exemplo, pela Smithsonian, que procuram estabelecer protocolos e regras de acesso a eles: no caso, por exemplo, dos povos que restringem determinados materiais às mulheres, os arquivos devem respeitar essa interdição, e a colocação de um ícone define se são apropriados ou não à audição pelas mulheres. Isso não resolve o problema da propriedade dos materiais, mas de algum modo respeita alguns princípios de classificação nativa desses materiais. Existem de fato muitas experiências interessantes com os arquivos, atentas à relação com as pessoas e os povos que foram objeto desses sons e imagens. Há, por exemplo, uma série de restrições em relação a filmes etnográficos realizados sobre esses povos que não devem ser vistos por pessoas ainda não iniciadas, e os arquivos devem conter, portanto, essa infomação de restrição. Muitos materiais estão hoje embargados em vários arquivos e só podem ser vistos ou ouvidos pelos membros da comunidade que os produziu.

Os arquivos são hoje um lugar fascinante e prioritário para pensarmos a questão da propriedade cultural. Por exemplo, o Museu Americano de História Natural tem vários filmes sobre iniciação masculina na Austrália, sobre circuncisão masculina. São filmes que deveriam ter a circulação restrita, mas eram usados em universidades nos Estados Unidos, no campo da psicologia, para estudos e mensuração da ansiedade em relação à castração em jovens. Instauraram-se então iniciativas em relação ao uso dessas imagens, de modo que as instituições não usem de modo indiscriminado um material que pertence a contextos privados de produção e exibição. Há muito ainda para se fazer nesse sentido, e cada vez mais os arquivos estão sendo regulados pelas comunidades sobre as quais as imagens foram produzidas. Como no caso exemplar do Vídeo nas Aldeias, no Brasil: cada vez mais os arquivos fílmicos que ali se encontram estão sendo orientados na direção dos interesses indí- 
genas. Filmes antigos retornam e são remontados pelas comunidades em suas produções. Esses são novos modos de retomar os arquivos, que podem suscitar novos materiais ou recuperar materias de outros modos mais ligados aos interesses e protocolos nativos.

Concedida em julho de 2016 | Aprovada em I5/og/2016

André Brasil é professor do Departamento de Comunicação e do Programa de Pós-Graduação em Comunicação da UFMG, doutor pela UFRJ, com pós-doutorado na New York University. Desenvolve pesquisas sobre e cinema e cinema documentário, com foco na produção de filmes por diretores e coletivos indígenas. Publicou recentemente "Ver por meio do invisível: o cinema como tradução xamânica” (20I6).

Marco Antonio Gonçalves é professor do Departamento de Antropologia e do Programa de Pós-Graduação em Sociologia e Antropologia (PPGSA) da UFRJ, e doutor pelo PPGAS do Museu Nacional/UFRJ. Publicou, entre outros, O real imaginado: etnografia, cinema e surrealismo em Jean Rouch (2008). 


\section{NOTAS}

I Ver especialmente alguns de seus artigos e livros (Ginsburg, I99I, I993, I995, 2002a, 2002b, 2003, 2005a, 2005b, 2006, 2008).

2 Annette Weiner (I933-I997) foi professora titular de antropologia e decana da Escola de Artes e Ciências da Universidade de Nova York. Realizou importante trabalho etnográfico no arquipélago de Trobriand, na Melanésia, desenvolvendo o conceito de "bens inalienáveis", que teve relevante impacto na teoria antropológica. Ao reestudar o célebre circuito das trocas do kula introduziu a discussão do gênero na teoria da dádiva, influenciando a chamada antropologia feminista vindoura.

3 Elizabeth Weatherford foi diretora fundadora do Centro de Filme e Vídeo do Museu do Índio Americano da Smithsonian Institution. Foi criadora do Native American Film + Video Festival (NAFVF), que desde I98I realizou I5 edições voltadas para o cinema indígena. Amália Córdova é doutora em cinema e antropologia pela Universidade de Nova York e colaborou intensamente na formação do acervo e na organização dos festivais de cinema indígena promovidos pelo Museu do Índio Americano.

4 Fred Myers (I948) é professor titular de antropologia na Universidade de Nova York e desde os anos 70 pesquisa e publica sobre os aborígenes da Austrália Central focalizando os temas da arte, colonialismo e cultura material.

5 Sol Worth (I922-I977), artista, pintor, professor de comunicação visual da Annenberg School for Communication, Universidade da Pensilvânia, foi idealizador, em I966, do projeto Navajo filming themselves realizado em parceria com John Aldair (I9I3-I997), professor de antropologia da San Francisco State University.

6 Vincent Carelli (I953) é indigenista e documentarista, criador do projeto Vídeo nas Aldeias (1987) que produz filmes e forma cineastas indígenas.

7 Terence Tuner (I936-20I5) foi professor da Universidade de Chicago e participou das pesquisas sobre os Jê do Brasil Central no âmbito do projeto Harvard-Brazil Central Project coordenado por David Maybury-Lewis nos anos 60. Pesquisou os Kaiapó e publicou inúmeros artigos sobre 
esse povo incluindo suas reflexões sobre a introdução do vídeo como ferramenta político-cultural.

8 Ver o site: https://www.isuma.tv/

9 Ver Nichols (I99I).

\section{REFERÊNCIAS BIBLIOGRÁFICAS}

Ginsburg, Faye (2008). Rethinking the digital age. In: Toybee, Janson \& Hesmondalgh, Desmond (orgs.). The media and social theory. New York: Routledge, p. I27-I44.

Ginsburg, Faye (2006). Rethinking documentary in the digital age. Cinema Journal, 46/I, p. 67-8I.

Ginsburg, Faye (2005a). Ciné-Trance: a tribute to Jean Rouch (I9I7-2004) - Special section. American Anthropologist, I07/I, p. I09-I 29.

Ginsburg, Faye (2005b). The unwired side of the digital divide. Flow: a critical forum on television and media culture, I.I2/I. Disponível em: <http://www.flowjournal. org/2005/03/the-unwired-side-of-the-digital-divide/28/Io/20I6.>. Acesso em 28 nov. 2016.

Ginsburg, Faye (2003). Indigenous media: negotiating control over images. In: Gross, Lary; Katz, Jonathon \& Ruby, Jay (orgs.). Image ethics in the digital age. Minneapolis: University of Minnesota Press, p. 295-312.

Ginsburg, Faye; Abu-Lughod, Lila \& Larkin, Brian (orgs.) (2002a). Media worlds: anthropology on new terrain. Berkeley: University of California Press.

Ginsburg, Faye (2002b). Screen memories: resignifying the traditional in indigenous media. In: Ginsburg,Faye; AbuLughod, Lila; Larkin, Brian (orgs.). Media worlds: anthropology on new terrain. Berkeley: California University Press, p. 245-256.

Ginsburg, Faye (I995). The parallax effect: the impact of aboriginal media on ethnographic film. Visual Anthropology Review, I I/2, p. 234-249.

Ginsburg, Faye (1993). Embedded aesthetics: creating a discursive space for indigenous. Media Cultural Anthropology, 9/2, p. 76-9I. 
578

Ginsburg, Faye (I99I). Indigenous Media: Faustian Contract or Global Village? Cultural Anthropology, 6/I, p. 92-I I 2. Ginsburg, Faye (1989). Contested lives: the abortion debate in an American community. Berkeley: University of California Press.

Nichols, Bill (I99I). Representing reality. Issues and concepts in documentary. Bloomington: Indiana University Press.

\section{Filmografia}

Atanarjuat ou Atanarjuat: The Fast Runner (200I). Canadá. Direção de Zacharias Kunuk.

Cocorico Monsieur Poulet (I 974). França-África. Direção de Jean Rouch.

Jaguar (1967). França-África. Direção de Jean Rouch.

Nanook of the North (I922). Estados Unidos-Canadá. Direção de Robert Flaherty. 
Palavras-chave

Cinema indígena;

Propriedade intelectual;

Era digital;

Antropologia visual;

Filme etnográfico.
Keywords

Indigenous cinema; Intellectual property;

Digital age;

Visual anthropology; Ethnographic film

\section{CINEMAS E MÍDIAS INDÍGENAS:}

\section{CONSTRUIR PONTES, RECUSÁ-LAS.} ENTREVISTA COM FAYE GINSBURG

\section{Resumo}

Anos dedicados às imagens produzidas por grupos nativos de várias partes do mundo permitiram a Faye Ginsburg acompanhar a historicidade das questões interculturais que se abrigam nas imagens, mas que as ultrapassam, exigindo metodologia atenta ao que está visível na tela e também ao que ocorre fora dela. Como defende a entrevistada, a atenção aos processos de produção e de circulação das imagens nos exige questionar a vocação de fluência e transparência própria da tradição imagética ocidental e considerar os protocolos de cada povo, muitas vezes construídos sobre o que se deve ocultar, mais do que sobre o que se deve revelar. Como se notará, a conversa extrapola as discussões em antropologia visual, colocando em evidência questões hoje cruciais, como aquelas em torno da mediação cultural, da era digital, propriedade intelectual, da devolução e reutilização dos arquivos étnicos.

\section{CINEMAS AND INDIGENOUS MEDIA: ON BUILDING AND REFUSING THEM. AN INTERVIEW WITH FAYE GINSBURG}

\section{Abstract}

The study of moving images produced by native groups around the world allowed Faye Ginsburg to address intercultural issues that demand a methodology attentive to what is visible on the screen as well as to what is out of screen. In this interview Faye Ginsburg expresses her points of view on ethnographic film, visual anthropology and films produced by the indigenous groups. As she argues, the circulation of images requires our attention in order to question the fluency and transparency that characterize the Western imagery tradition. The conversation goes beyond the discussions on visual anthropology, highlighting issues such as cultural mediation, intellectual property, the return and reuse of ethnical archives. 